\title{
The Role of the Apostates in the Twelve Tribes conflict in Germany
}

\author{
Zdeněk Vojtíšek
}

https://doi.org/10.14712/25704893.2017.7

\begin{abstract}
The testimonies of the apostates and their captivity narratives and atrocity tales often have a great impact on the conflict between new religious movements and general society. The reason behind this is both the great persuasive power that those narratives wield, which stems from personal experience, and the negative bias of the public that seldom questions their truthfulness and accuracy. One of the examples of apostates' narratives largely contributing to a violent solution of a conflict with a New Religious Movement, is the case of the Twelve Tribes. The article describes the role of the apostates that led to a raid on a German community of this movement in 2013 and pursues parallels with the raid on a community of the same movement in 1984 in Vermont. The text also briefly mentions other violent conflicts in new religious movements at large.
\end{abstract}

Keywords: Twelve Tribes movement, New Religious Movements, religious community, apostasy, raid, "captivity narratives", "atrocity tales"

\begin{abstract}
Abstrakt: Svědectví apostatů a jejich „příběhy zajeti“ a "ohavné historky" vstupují do konfliktů nových náboženských hnutí a většinové společnosti obvykle s velkou razancí. Je způsobena přesvědčivostí těchto narací vyplývající z osobní zkušenosti i tím, že negativně naladěná veřejnost obvykle nijak nezpochybňuje jejich pravdivost a přesnost. Jedním z nových náboženských hnutí, v jejichž př́ípadě narace apostatů významně přispěly $\mathrm{k}$ pokusům o násilné řešení konfliktů, je hnutí Dvanáct kmenů. Článek popisuje roli apostatů $\mathrm{v}$ okolnostech razie $\mathrm{v}$ komunitě tohoto hnutí v Německu roku 2013 a naznačuje paralely $\mathrm{s}$ razií $\mathrm{v}$ komunitě téhož hnutí ve Vermontu roku 1984, okrajově též s násilnými událostmi v jiných nových náboženských hnutích.
\end{abstract}

Klíčová slova: hnutí Dvanáct kmenů, nová náboženská hnutí, náboženská komunita, apostaze, razie, „příběhy zajetí", „ohavné historky“

Received: 28 March 2017, Accepted: 22 May 2017

Published online: 13 November 2017

doc. ThDr. Zdeněk Vojtíšek, Th.D.

Department of Comparative Religions, Hussite Theological Faculty of the Charles University e-mail: zdenek.vojtisek@htf.cuni.cz

(c) 2017 The Author. This is an open-access article distributed under the terms of the Creative Commons Attribution License (http://creativecommons.org/licenses/by/4.0), which permits unrestricted use, distribution, and reproduction in any medium, provided the original author and source are credited. 


\section{Topic, goal and structure of the article}

In 1998, the Canadian sociologist Susan Palmer published a study titled "Apostates and their Role in the Construction of Grievance Claims Against the Northeast Kingdom/Messianic Communities". ${ }^{1}$ In this text, Palmer described three successive stages of the conflict, which culminated in 1984, when 112 children were unwillingly removed from their families, all part of this New Religious Movement. During each and every one of these stages the apostates played an important - perhaps even crucial - role. In the three decades that followed after this Vermont incident, both the Western society and the movement (which today calls itself "the Twelve Tribes") have undergone important changes. Nevertheless, the raid that took place in 2013 in two Twelve Tribes' communities in Germany, during which 40 children $^{2}$ were taken away, shows important similarities with the Island Pond raid. One of them is the role of the apostates in the events that happened both before and after the raid. The goal of this article is to explore the influence of the apostates on the recent German case, compare it to the influence their predecessors had on the Island Pond events, and outline some general rules discernible in the apostates' role in conflicts related to New Religious Movements. This article therefore aims to follow up on Palmer's study and widen its scope on a different society in a different time.

First, I will focus on the key terms of "apostasy" and "apostate" in the context of Comparative Religions and Sociology of New Religious Movements. In the following paragraphs, I will sum up basic facts concerning the Twelve Tribes movement, the Island Pond raid, and the role of apostates as described by Palmer. In the main part of the article I will then give a concise summary of the events related to the German raid and present the available information about those apostates who contributed to it in an important manner. I will then conclude by formulating some observations about the role of apostates in general.

\section{Apostasy as a specific way to leave a community}

Although some scholarly publications contain revealing insights into the situation of ex-members, ${ }^{3}$ any discussion of the different attitudes these ex-members have to their community of origin still forms rather a marginal part of Comparative Religions and

1 Susan Palmer, "Apostates and their Role in the Construction of Grievance Claims Against the Northeast Kingdom/Messianic Communities”, in David, G. Bromley, (ed.), The Politics of Religious Apostasy: The Role of Apostates in the Transformation of Religious Movements, Westport, London: Praeger 1998, p. 191-208.

2 According to the last academic presentation of the Twelve Tribes member, the number of seized children is 41. Jean Swantko Wiseman, "Spanking Bans and the Faith of Families: The Twelve Tribes in the European Court of Human Rights", a paper presented at CESNUR conference, Jerusalem, 3. 7. 2017.

3 James beckford, Cult Controversies: The Societal Response to the New Religious Movements, London, New York: Tavistock 1985, s. 149-189. 
Sociology. ${ }^{4}$ A greater interest in the role of apostates was brought about by the examination of the tragic end of the Peoples Temple and especially the Branch Davidian movement. ${ }^{5}$ In the latter case, the actions of Marc Breault, an apostate, were without a doubt one of the key factors. ${ }^{6}$ Other violent events of the 90 s led to the publication of a groundbreaking book on apostasy. ${ }^{7}$ Its editor, David G. Bromley suggested a typology of ex-members by their relationship to their community of origin. Among these terms, "apostate" became the most influential and some definitions of apostasy appeared. Especially Bromley created a preliminary definition of apostasy as a "role that is constructed when an organization is in a state of high tension with its surrounding environment and that involves an individual exiting the organization to form an alliance with oppositional coalition." ${ }^{8}$ An openly hostile approach to the abandoned community and an alliance with its opposition in a situation of tension are the core traits that also appear in other definitions of apostate and/or apostasy. ${ }^{9}$ Typically, we may emphasize the label of "traitor" given to the apostate by his or her former co-members. ${ }^{10}$

This means that apostasy is a specific type of leaving a community. A great majority of the members "exit voluntarily after some period of experimentation and typically seek a low-profile re-entry into conventional networks by resuming familial, occupational and educational endeavors." 11 The reason why this low-profile exit appears so frequently is without a doubt the result of the fact that in most cases, the "membership has constituted a period of experimentation rather than a long-term commitment." 12 The exiting member typically relates his or her experience to a wider biographical context and the membership in a new religious movement may be interpreted as a necessary or meaningful step in his or her spiritual, emotional or

\footnotetext{
${ }^{4}$ A classical study by Stuart A. Wright (Leaving Cults: The Dynamics of Defection, Washington: Society for the Scientific Study of Religion 1987) does not offer data or theories about these stances. Even the new chapter on leaving New Religious Movements mentions apostasy only very briefly. DAvid G. BRomLeY, "Leaving the Fold. Disaffiliating from New Religious Movements", in James R. Lewis, The Oxford Handbook of New Religious Movements, Oxford etc.: Oxford University Press 2004, p. 298-314.

${ }^{5}$ John R. Hall, "The Impact of Apostates on the Trajectory of Religious Movements: The Case of Peoples Temple", in David G. Bromley (ed.), Falling from Faith: Causes and Consequences of Religious Apostasy, Newbury Park: Sage Publications 1988, p. 229-250.

${ }^{6}$ See John R. HALL, "Public Narratives and the Apocalyptic Sect", in Stuart A. Wright (ed.), Armageddon in Waco. Critical Perspectives on the Branch Davidian Conflict, Chicago, London: The University of Chicago Press 1995, p. 212-228; James D. TaboR and Eugene V. Gallagher, Why Waco?, Berkeley etc.: University of California Press 1995, p. 80-93.

7 David G. Bromley (ed.), The Politics of Religious Apostasy: The Role of Apostates in the Transformation of Religious Movements, Westport, London: Praeger 1998, 244 p.

${ }^{8}$ David G. Bromley, "The Social Construction of Contested Exit Roles: Defectors, Whistleblowers, and Apostates", in David G. Bromley (ed.), The Politics of Religious Apostasy: The Role of Apostates in the Transformation of Religious Movements, Westport, London: Praeger 1998, p. 19.

9 See Stuart A. Wright, "Exploring Factors That Shape the Apostate Role", in David G. BromLEY (ed.), The Politics of Religious Apostasy: The Role of Apostates in the Transformation of Religious Movements, Westport, London: Praeger 1998, p. 109.

${ }^{10}$ According to Massimo InTrovigne, "Defectors, Ordinary Leave-takers, and Apostates: A Quantitative Study of Former Members of New Acropolis in France", Nova Religio 3 (1, 1999): p. 84.

${ }^{11}$ Bromley, "The Social Construction...", p. 40.

${ }^{12}$ Bromley, "The Social Construction...”, p. 39.
} 
social development. Even though former members evaluate their experience with the new religious movement on a wide scale ranging from positivity through ambivalence to disillusion, ambivalence (which correlates with a non-conflictive type of exit) remains the most common. ${ }^{13}$ In sum, only a minor part of leave-takers adopt the open hostility of an apostate. ${ }^{14}$

The probability of apostasy greatly rises in those communities where the relationship to the surrounding society is marked by high levels of tension. This kind of community is typically less able to control the exit process of its members, ${ }^{15}$ while at the same time it may be forced to deal with more or less organized opposition formed by apostates, civil activists (family members and other critics of the movement), mass media, law-enforcement authorities etc. Due to the existence of tension and opposition, the movement may create strong and impenetrable barriers that prevent exiting. By "barriers" I mean for example demonization of the leave-takers, which implicates punishment that would befall them and those who keep in contact with them. ${ }^{16}$ For a member of this type of movement, to cross such a barrier may lead to very traumatic experiences. Moreover, another difficult life situation may follow - those, who remain in the community, may persecute the ex-members with expressions of hate.

Such an experience can decrease the gap between former members and any opposition against their community of origin. This is because the opposition can help the leave-takers in their difficult situation that arises from the loss of their religious life goal and the breakup with their closest, sometimes even their only close friends. Pressed by a necessity to understand all the reasons and circumstances behind their membership in a new religious movement, the ex-members may be ready to adopt an explanatory framework offered by the opposition. Most frequently, they tend to adopt the terminology of the popular brainwashing theory. Identification with the role of an apostate therefore alleviates the guilt the ex-member feels as a result of the questionable acts he or she engaged in while still in the community - and also helps to reestablish his or her place in society. The apostate's role thus serves a restitutive function in the social structure. ${ }^{17}$ The opposition acts as an audience that appreciates and affirms his or her traumatic experiences ${ }^{18}$ and the apostate gains their approval by compliance and meeting their expectations. In this process, the apostate becomes a part of the opposition.

Conversely, the apostate also provides a great help for the opposition, as he or she becomes an important protagonist in their struggle with the movement. In the allegorical words of Susan Palmer, "the 'moves' of apostates resemble those of the knight

${ }^{13}$ Wright, Leaving Cults, p. 88-91.

${ }^{14}$ BRomley, "The Social Construction...", p. 40.

${ }^{15}$ BROMLEY, "The Social Construction...", p. 25.

${ }^{16}$ Marc Galanter, Cults. Faith, Healing, and Coercion, New York, Oxford: Oxford University Press 1999, p. 105-109.

${ }^{17}$ Wright, "Exploring Factors...", p. 110.

${ }^{18}$ Armand L. Mauss, "Apostasy and the Management of Spoiled Identity", in David G. Bromley (ed.), The Politics of Religious Apostasy: The Role of Apostates in the Transformation of Religious Movements, Westport, London: Praeger 1998, p. 69. 
in a chess game." ${ }^{19}$ If the apostate's personal story is formulated along the lines of a captivity narrative ${ }^{20}$ (which happens very often), the apostate becomes a deceived, blameless victim; the opposition is stylized as a group of heroes; and the conflict becomes a war against evil. ${ }^{21} \mathrm{~A}$ similar effect is produced by the so-called "atrocity tales". ${ }^{22}$ In other words, the apostate tells stories of moral failure whose chief actors are the members of his or her former movement, especially its leadership. Such tales may of course be entirely or partly true, but they are often one-sided and deprived of context all the same. With the help of captivity narratives and atrocity tales, the apostates sometimes succeed in degrading their former communities' moral status and ethically justify the more repressive actions of the opposition. ${ }^{23}$ In this kind of struggle, the media are especially effective. ${ }^{24}$

However, we must keep in mind that it is always the oppositional audience that has the power to bestow the role of an apostate on an ex-member. Research confirms ${ }^{25}$ that an overwhelming majority of apostates have apparently had contact with an oppositional coalition of some kind. ${ }^{26}$ The strength and power of the oppositional public is after all well attested by the phenomenon of "apostates who never were." 27 The phenomenon probably arises in those situations when, due to a high tension between a religious movement and its surrounding environment, the demand for captivity narratives and atrocity tales surges so much that people pretend to be apostates and provide this kind of stories. Examples of specific cases of these situations may be the great surge of hostility towards the Roman Catholic Church in the second third of the $19^{\text {th }}$ century in the United States, or ${ }^{28}$ the 1980 s and 1990 s so-called Satanic panic in the West. $^{29}$

19 PAlmer, “Apostates and their Role...”, p. 193.

${ }^{20}$ WRIGHT, “Exploring Factors...”, p. 97-100.

${ }^{21}$ Wright, “Exploring Factors...”, p. 98, 110.

22 Anson D. Shupe and David G. Bromley, "Apostates and Atrocity Stories: Some Parameters in the Dynamic of Deprogramming”, in Bryan Wilson (ed.), The Social Impact of New Religious Movements, Barrytown: Rose of Sharon Press 1981, p. 179-234.

${ }^{23}$ Bromley, “The Social Construction...”, p. 42.

${ }^{24}$ James Beckford, “The Media and New Religious Movements”, in James R. Lewis (ed.), From the Ashes. Making Sense of Waco, Lanham: Rowman and Littlefield 1994, p. 143-148.

${ }^{25}$ Trudy Solomon, “Integrating the 'Moonie' Experience: A Survey of Ex-Members of the Unification Church", in Thomas Robbins and Dick Anthony (eds.), In Gods We Trust: New Patterns of Religious Pluralism in America, Princeton: Rutgers University Press 1981, p. 275-294; JAMES R. LEWIS, “Reconstructing the 'Cult' Experience: Post-Involvement Attitudes as a Function of Mode of Exit and Post-Involvement Socialization”, Sociological Analysis, 47 (2, 1986): p. 151-159.

${ }^{26}$ Introvigne, “Defectors...”, p. 96.

${ }^{27}$ Daniel Carson Johnson, "Apostates Who Never Were: The Social Construction of Absque Facto Apostate Narratives”, in: David G. Bromley (ed.), The Politics of Religious Apostasy: The Role of Apostates in the Transformation of Religious Movements, Westport, London: Praeger 1998, p. 115-138.

${ }^{28}$ In this case, the role of an "apostate that never was" was played by a Canadian by the name of Maria Monk, the author of Awful Disclosures by Maria Monk of the Hotel Dieu Nunnery of Montreal published in 1836.

${ }^{29}$ The probably most famous "apostates that never were" were the popular book authors Michael Warnke (The Satan Seller, 1972) and Laurel Rose Willson (Satan's Underground, published 1988 under the pen name of Lauren Stratford). 


\section{A brief characteristic of the Twelve Tribes Movement and the circumstances of the 1984 Island Pond Raid}

The new religious movement of the Twelve Tribes ${ }^{30}$ emerged in 1972 from the environment of the American Jesus movement, a current which formed a part of the Hippies movement. Today it consists of roughly 2,500 persons that live in more or less 50 communities spread across 9 countries. ${ }^{31}$ By means of applying biblical texts on faith, liturgy, ethics and communitarian lifestyle, the Twelve Tribes fulfill their concept of an ideal organization of a Christian church, modeled on the Early Christian example and closely related to its Jewish heritage. At the same time, according to them, only their movement represents the true people of God and the origin of the community is interpreted in terms of the last era of human history. The movement aspires to become a spiritual bride of Jesus (called Yahshua) during his imminent Second Coming. Literally interpreted biblical texts along with Jewish cultural elements and communitarian principles, combined to create a typical culture, which has diligently guarded its specificity without isolating itself from its surroundings.

One of the characteristic traits of this culture is the upbringing of children, which is considered to be the most important task of a member of the movement. ${ }^{32}$ The importance stems from the eschatological dimension of the movement: the children are going to become the fourth generation of the community ${ }^{33}$ that has been gradually purged from the sins of the forefathers. ${ }^{34}$ An immaculate "bride", this generation will come forward to meet the arriving Yahshua and especially the boys will play a key role in these eschatological events. ${ }^{35}$ The most important part of their education is to learn obedience and submission to authorities. ${ }^{36}$ Some elements of the training have become a seed of conflict and confrontation with the general society. Most of those conflicts arise from the movement's rule of physical punishment of children, which

${ }^{30}$ For a general survey of this movement with a special attention to the raids against the communities see Stuart A. Wright and Susan J. Palmer, Storming Zion: Government Raids on Religious Communities, New York: Oxford University Press 2016, p. 47-72.

${ }^{31}$ Robert Pleyer and Axel Wolfsgruber, Der Satan schläft nie: Mein Leben bei den Zwölf Stämmen, München: Knaur 2014, p. 177. Acording to the movement itself, the number may be as high as three thousand members.

32 "We believe that the most important job on earth for the church is to train its children to enter the kingdom of heaven." “The Education of our Children”, Island Pond, October 1979, in Foundational Teachings of the Twelve Tribes. Book Two (Di-G), Parchment Press, p. 135.

${ }^{33}$ Our Child Training Manual II., part 12: What Discipline is Not (online), 2000, retrieved 21.3.2017, p. 77, available online at https://assets.documentcloud.org/documents/2994399 /OUR-CHILD-TRAINING-MANUAL.pdf.

${ }^{34}$ Based on the Bible: “... for I the LORD your God am a jealous God, visiting the iniquity of the fathers on the children to the third and the fourth generation of those who hate me, but showing steadfast love to thousands of those who love me and keep my commandments" (Ex 20: 5-6).

35 The Purpose of Creation \& Redemption (online), a Twelve Tribes freepaper, TwelveTribes. com, retrieved 21. 3. 2017, available online at http://www.twelvetribes.com/articles/purpose -creation-redemption.

36 Our Child Training Manual, p. 10. 
consists of spanking with a narrow, flexible stick ${ }^{37}$ on the buttocks. ${ }^{38}$ The punishment is executed by parents or other adult members of the community, which must not be angry at the time of the act. This biblically sanctioned type of punishment is supposed to save the children for the eternal life. ${ }^{39}$ Other causes for conflict have been the intent of the Twelve Tribes to offer homeschooling to their children and thus protect them from the influence of the public educational system; the joint work of parents and children; simple measures taken to protect their health; restricting the cultural influence of society at large, especially with respect to mass media; etc. Subsequently the Twelve Tribes have been accused of misusing and abusing children, inappropriate discipline methods, restricting the children's access to education and medical services, isolating the children from the society, etc. These accusations have been countered by positive testimonies, medical, psychological and pedagogical, and the ability of the second- and third-generation members to create a self-sufficient and viable community.

During most of the movement's existence, every community has been generally able to maintain a reasonable level of tension with the surrounding society and to find enough supporters and advocates to maintain a balance of forces with its opponents. Until now, breaches of this balance were mostly brought about by apostates, who nevertheless formed only a very small part of the movement's ex-members. These apostates have been recruited both from adult neophytes and adults and young adults who grew up in the movement.

As Susan Palmer described in the aforementioned study, it was these apostates who played a crucial role in the escalation of the 1980s conflict: at that time, the movement mainly consisted of one community located in Island Pond, Vermont, USA. The conflict was sparked by arguments against the movement that arose during court battles for child custody. In 1983, the courts decided to place a total of 11 children in the custody of three fathers who were apostates and were not living with the community. The doubts concerning the fairness of this decision started to appear years later when most of these children (now adults) returned to the community. ${ }^{40}$ The most important figure among these apostates was a Chilean hippie Juan Mattatall, who had been expelled by the movement after sexually harassing community girls, which caused his wife to divorce him. Mattatall blamed the community for his divorce and allegedly wowed to destroy the movement. The following struggle of a wide coalition of media, civil activists and apostates against the community and an outbreak of a negative image of

${ }^{37}$ Our Child Training Manual, p. 72.

38 Our Child Training Manual II., part 11: Chastisement (online), 2000, retrieved 21. 3. 2017, p. 75, available online at https://assets.documentcloud.org/documents/2994399/OUR-CHILD -TRAINING-MANUAL.pdf. The Manual goes on to say that the "objective of discipline is not to cause pain, stripes, tears, or sorrow, but to bring the rebellious child's will under control. It does not break a child's spirit to force him to obey. It causes him to choose obedience over rebellion."

${ }^{39}$ For more details on the education of children see SusAn J. PAlmer, "Frontiers and Families: The Children of Island Pond", in Susan J. Palmer and Charlotte E. Hardman (eds.), Children in New Religions, New Brunswick: Rutgers University Press 1999, p. 157-161.

40 PAlmer, "Apostates and their Role...”, p. 206. 
the movement led to the fact that Mattatall was awarded custody of all his five children despite being suspected of child molestation. Indeed, years later doubt was cast on the court ruling, since Mattatall was subsequently convinced of child sexual abuse. ${ }^{41}$

Hostile actions of two other apostates, Michael Taylor and Roland Church, a dispute over an autopsy of a stillborn child in the community, and a congenital defect of another child contributed to new charges and further escalation of the tension in 1983 and 1984. This gave a chance to the opposition to include the District Attorney into the hostile actions. ${ }^{42}$ As a result, in June 1984 a police raid was organized, during which 20 community houses were searched and 112 children taken away. Their parents accompanied them to court. Nevertheless, after 40 individual hearings the judge decided the detention order was unconstitutional and he refused to allow the children to be unwillingly examined. Quite the opposite happened - the children were returned to their parents on the same day.

\section{The 2013 raid on the German communities and the role of apostates in the conflict}

A German Twelve Tribes community had to live through a similar set of events. The Klosterzimmern community was founded in 2001 and in the early years went through a difficult struggle for homeschooling which ended peacefully in 2006. The truce between the government agencies and the German Klosterzimmern community lasted until 2013.

The incidents that took place in the second half of the year had been preceded by the Reip family's exit from the movement - this important family left the Klosterzimmern Twelve Tribes in 2010. The exit was initiated by the then $17-y e a r^{43}$ old Christian Reip (whose community name was Zakar) about two weeks after his older sister and her husband left the community. Christian was joined by his younger sister Amit$\mathrm{sa}^{44}$ and then also by their parents and two other siblings. Of the whole family, only one daughter remained in the Twelve Tribes. From all the eight Reip ex-members (including the husband of the eldest daughter), only Christian Reip became an apostate in the aforementioned sense. In the media, he has mainly accused the community

${ }^{41}$ Palmer, “Apostates and their Role...”, p. 194-198.

42 PAlmer, “Apostates and their Role...”, p. 198-201.

${ }^{43}$ Vivian Herbrich, “Die unheimliche Sekte 'Zwölf Stämme': Ein Aussteiger packt aus” (online), Huffington Post, 17. 6. 2014, retrieved 10. 9. 2016, available online at http://www.huffingtonpost .de/2014/06/17/sekte-zwoelf-staemme-aussteiger-packt-aus_n_5499399.html.

${ }^{44}$ Frauke Lüpke-Narberhaus, "Leben nach der Sekte: 'Ich habe keine Wurzeln und keine Kraft zu fliegen’” (online), Spiegel Online, 27. 1. 2014, retrieved 10. 9. 2016, available online at http:// www.spiegel.de/lebenundlernen/schule/zwoelf-staemme-wie-eine-aussteigerin-versucht-ins -leben-zu-finden-a-944962.html. 
of robbing him of his childhood. His relationship to his parents has suffered as well: he has blamed them for letting the Twelve Tribes ruin his life. ${ }^{45}$

Christian's childhood friend, using the name Aaron, ${ }^{46}$ joined him in his severe criticism of the movement. Aaron left the community in 2008 as a fifteen-year-old; his father accompanied him and stayed with him until his son reached adulthood. Even though the father rejoined the community after this, he is currently living outside of the community again, as do his two sons, while Aaron's mother remained in the community with her two younger daughters. Aaron expressed his anger with his former community in his 2012 article published in the Focus magazine. Nine other ex-members, most of whom belonged to the Reip family, also contributed (albeit rather marginally). ${ }^{47}$ Aaron's (and the others') testimonies quoted in the article bear clear marks of captivity narratives. Aaron told the magazine that the community has "a perfect facade", behind which, nevertheless, the members "break children's wills" and "they chase all their individuality out of them". According to Aaron, this "brainwashing" leads to the fact that the young people are "almost incapable of an existence outside of the movement." 48

Aaron also published his opinion of the Twelve Tribes in a text of his own. ${ }^{49}$ Among other things, he expressed a wish to contribute to outlawing the Twelve Tribes movement not only in Klosterzimmern, but in the whole world. ${ }^{50}$ The text contains a second-hand atrocity tale of how the leaders of the movement enjoy vast riches while many children of the community lack even good shoes or decent clothing. ${ }^{51}$ In relation to this claim, Aaron holds that "the cult created a perfect facade" and the members of the community "spread lies" among the non-members. ${ }^{52}$

Just like Aaron, the most important German apostate Robert Pleyer (known as Yathar in the community) also spoke about "facade": "behind the facade of an alternative lifestyle with farmer's yard shops and happy feasts complete with goat goulash

${ }^{45}$ PAtrick Guyton, "Ich hatte keine Kindheit. Ich habe geschufftet" (online), Der Tagesspiegel, 17. 6. 2014, retrieved 10. 9. 2016, available online at http://www.tagesspiegel.de/themen /reportage/sekte-zwoelf-staemme-ein-aussteiger-erzaehlt-ich-hatte-keine-kindheit-ich-habe -geschuftet/10044034.html.

${ }^{46}$ In this way, he conceals not only his civic name but the name received in the Twelve Tribes movement as well. In this article, we respect this decision of his.

${ }^{47}$ In the Focus article, their names were changed.

48 Axel Wolfsgruber, „Sekten-Aussteiger: “Sie brechen Deinen Willen” (online), FOCUS Magazin 21 (2012), 21. 5. 2012, retrieved 10.9. 2016, available online at http://www.focus.de/magazin /archiv/tid-26021/glaubensgemeinschaft-zwoelf-staemme-im-focus-report-sekten-aussteiger -sie-brechen-deinen-willen-nochmal-aendern_aid_762194.html.

49 This text was published as part of the following book: RoBERT PLEYER and AxeL WoLfsgruber, Der Satan schläft nie: Mein Leben bei den Zwölf Stämmen, München: Knaur 2014, p. 157-172.

50 Aaron in Pleyer and Wolfsgruber, Der Satan schläft nie, p. 171: "Ich möchte meinen Teil dazu beitragen, dass die Zwölf Stämme in Klosterzimmern, aber auch weltweit verboten werden."

51 Aaron in Pleyer and Wolfsgruber, Der Satan schläft nie, p. 164-165: "Ich habe bespielweise damals gehört, dass der Sektengründer sich alle paar Monate für 30000 bis 60000 Euro ein neues Auto kauft, das nur er selbst fahren kann, während manches Kind in der Gemeinschaft nicht mal vernünftige Schuhe oder Kleidung zum Anziehen hat.”

52 Aaron in Pleyer and Wolfsgruber, Der Satan schläft nie, p. 164. 
and folklore dances, which aim to bring a nice experience to the neighbourhood and show them how beautiful the Twelve Tribes movement is, something monstrous is happening. Male and female seekers alike bow to a system that knows no individuality. Both individuals and families live a life that is entirely at the mercy of arbitrary rules imposed by a council of elders." ${ }^{3}$ This so-called facade is related to Robert Pleyer's public actions as an apostate: "I want to show that behind the loving facade of the movement lurks a brutal regime that oppresses individuals and makes them unable to decide about their own life." 54

After an initial period of doubt and crises of faith, in the 1990s Robert Pleyer became a firm part of the movement under the name of Yathar. He helped to build the German communities in Penningbüttel near Bremen and in Stödtlen-Oberbronnen in Baden-Würtenberg. In 2001 these communities founded a new base in Klosterzimmern in Bavaria and here Yathar became an important community member: he helped create a schooling system for children ${ }^{55}$ and in 2003 he became a member of an important family by marrying Shaloma. Efraim, his father-in-law, was one of the first German disciples and since he refused to send Shaloma to a public school, he had a prison experience. ${ }^{56}$ In the U. S., her country of origin, Yathar's mother-in-law Baruchah suffered abduction and a so-called deprogramming, after which she managed to escape back to her community under dramatic circumstances. ${ }^{57}$ After her third child was born, Shalomah started suffering from a mental disorder and in 2009, in response to growing set of problems, the family tried for the first time to live outside of the community. An ensuing period of repeated exits and re-entries lasted until 2011 when the marriage finally broke up. While Shalomah firmly reestablished her place in the community, Yathar, along with their four children, left. ${ }^{58}$

A few months later, Pleyer accepted the role of an apostate. The core motivation to his struggle with his former community was - as he puts it - problems in communication with Shalomah. Their contact was complicated and protracted, as it was mediated by an elder council of the community, in which Shalomah resided. In a situation when he needed his wife's legal assent again, Pleyer announced to one of the council members his intention to go to court and ask to be the only custodial parent. The elder strictly refused this scenario and expressed the community's determination to prevent it. Both men argued and Pleyer threatened to "tell people how things work in the community." The elder responded: "If you want war, you'll get it." ${ }^{59}$ After

53 Claudia Becker, „Sekten-Ausstieg: “Ich konnte einfach keine Kinder mehr schlagen” (online), Welt, 9. 10. 2014, retrieved 10. 9. 2016, available online at https://www.welt.de/vermischtes /article133084896/Ich-konnte-einfach-keine-Kinder-mehr-schlagen.html.

54 Pleyer and Wolfsgruber, Der Satan schläft nie, p. 265.

55 Pleyer and Wolfsgruber, Der Satan schläft nie, p. 48.

56 Pleyer and Wolfsgruber, Der Satan schläft nie, p. 232.

57 Pleyer and Wolfsgruber, Der Satan schläft nie, p. 122-125. The same story is told in "The Kidnapping of Rebecca Westbrooks" (online), TwelveTribes.org, retrieved 27. 3. 2017, available online at http://twelvetribes.org/controversies/kidnapping-rebecca-westbrooks.

58 The breakup of the marriage as described according to PLEYER and Wolfsgruber, Der Satan schläft nie, p. 249.

59 The conversation is reported in Pleyer and Wolfsgruber, Der Satan schläft nie, p. 259-260. 
this Robert Pleyer started with his hostile appearances in media, he contacted other former members of the movement and possibly even encouraged Christian Reip and Aaron to appear in the media as well. ${ }^{60}$ The author of the first article that sparkled this wave of media interest in the Twelve Tribes was Axel Wolfsgruber. Pleyer knew Wolfsgruber from 2002 when the journalist visited the Klosterzimmern community and subsequently published a news report about the struggle between the community and government agencies, which was caused by the fact that the members did not send their children to school. ${ }^{61}$

In 2012 (i.e. in the same year), Shalomah lost her parental rights. ${ }^{62}$ In 2013, Pleyer was contacted by an investigative reporter by the name of Wolfram Kuhnigk ${ }^{63}$ who worked for the RTL media company (Radio Television Luxemburg). Kuhnigk subsequently visited Klosterzimmern three times between June and August 2013 and was accepted with trust, thanks to a story about his alleged painful divorce. Acting on Pleyer's information, Kuhnigk installed hidden cameras in one of the houses, focusing them on a place that was reserved for the physical punishments of children. The cameras filmed mothers who punished their children by spanking them three or four times on their backside with a flexible rod. Kuhnigk then created a movie from the footage by adding dramatic effects and omitting scenes of reconciliatory embraces and dialogues that form a standard part of the Twelve Tribes child rearing practices. Kuhnigk showed his movie to the director of the Office of Youth Services as well as an expert on new religious movements from the Lutheran Church. Based on this movie, a decision was made to take the community's children away. This happened during a raid that took place on $5^{\text {th }}$ of September, $2013 .{ }^{64}$

On this day at 6:00 AM, the social workers accompanied by roughly 100 policemen made a surprise visit in the Klosterzimmern community (and in a house in Wörnitz). Altogether, they took away 40 children, including those that were only visiting the community with their parents. The children were placed in children's homes and surrogate families. Several days later Kuhnigk's film was broadcasted on RTL, the most popular private television in Germany, and both this network and other media adopted the narrative according to which the children were "freed" from the community. ${ }^{65}$ Even though none of the children showed any signs of abuse, the influence of the movie on the public was considerable and led to a discourse that used expres-

\footnotetext{
${ }^{60}$ This belief was expressed by Twelve Tribes members Obadiah, Caleb and Yerushah in a conversation that took place on March 192017.

${ }^{61}$ See Axel Wolfsburger, "Der Krieg um Gottes Kinder” (online), FOCUS Magazin 47 (2002), 18. 11. 2002, retrieved 14. 3. 2017, available online at http://www.focus.de/panorama/reportage /reportage-der-krieg-um-gottes-kinder_aid_206210.html.

${ }^{62}$ Pleyer and Wolfsgruber, Der Satan schläft nie, p. 261.

${ }^{63}$ Pleyer and Wolfsgruber, Der Satan schläft nie, p. 263-264.

${ }^{64}$ The source of these informations is SusAn J. PALMER, "Sekten in Germany: The Case of the Twelve Tribes”, a paper presented at the IAHR Conference, Erfurt, 27. 8. 2015.

${ }^{65}$ Such as the RTL TV internet news: "Razzia bei Sekte '12 Stämme' - RTL-Reporter liefert Beweise für Kindesmisshandlung” (online), RTLNext.RTL.de, 5. 8. 2014, accessed 10. 9. 2016, available online at http://rtlnext.rtl.de/cms/razzia-bei-sekte-12-staemme-rtl-reporter-liefert-beweise -fuer-kindesmisshandlung-1620767.html.
} 
sions such as "horrid cult", ${ }^{66}$ "brutal discipline" ${ }^{67}$ or "psychological terror" ${ }^{68}$ Along with the theme of punishment, the following wide public discussion of the Twelve Tribes also focused on the children's education, isolation, healthcare quality, physical labour, education oriented on the relationship to ethnic and sexual minorities and many other topics. Robert Pleyer's 2014 book Der Satan schläft nie: Mein Leben bei den Zwölf Stämmen (Satan Never Sleeps: My Life Among the Twelve Tribes) provided a new impulse for this discussion.

The framework for the actions of the authorities was both German Civil Law Code from 2000 that grants a right to a nonviolent upbringing to children ${ }^{69}$ and the principle of preventive care, which gives the governmental agencies the right to act preventively before the children are actually hurt. It is precisely this point that forms the foundation of the viewpoint of the movement's critics. They insisted that the children's physical presence in the community is harmful and limiting in itself. This principle may also be the reason why some courts have already decided to take some children away from their parents permanently and why in other cases the courts keep putting their decision off (even though more than four years have passed) and make any contact between the parents and the child quite complicated. As of yet, no proof of child abuse has been presented to the courts and the authorities' decisions have also affected children whose physical punishment did not appear on the investigative journalist's camera. Some children managed to escape from the surrogate care. ${ }^{70}$ During 2015 and 2016, the members of the Twelve Tribes gradually left Klosterzimmern and Wörnitz. Some of them joined Czech communities, both the older one in Mšecké Žehrovice and a newly founded one in Skalná in the Cheb region.

\section{The circumstances of the Klosterzimmern raid and their contribution to the discussion on the origins of apostasy and the role of the apostates}

The circumstances of the raid on the Twelve Tribes Klosterzimmern community in September 2013 allow a preliminary formulation of these five observations:

${ }^{66}$ Herbrich, “Die unheimliche Sekte...”, http://www.huffingtonpost.de/2014/06/17/sekte-zwoelf -staemme-aussteiger-packt-aus_n_5499399.html.

${ }^{67}$ ClaudiaFrickel, “Die ‘ZwölfStämme’: BrutaleErziehungundstrengeRegeln”, Web.de, 23. 5. 2016, retrieved 10. 9. 2016, available online at https://web.de/magazine/wissen/zwoelf-staemme -brutale-erziehung-strenge-regeln-31575188.

${ }^{68}$ BECKER, “Sekten-Ausstieg”, https://www.welt.de/vermischtes/article133084896/Ich-konnte -einfach-keine-Kinder-mehr-schlagen.html.

69 \ 1631 section 2 says: "Körperliche Bestrafungen, seelische Verletzungen und andere entwürdigende Maßnahmen sind unzulässig”.

${ }^{70}$ The stories of the children that had been taken away during the $5^{\text {th }}$ September 2013 raid are available in the following article: "Deutschland, wie behandelst Du unsere Kinder?" (online), News Zwölf Stämme Herzlich Willkommen, 14. 6.2016, retrieved 10. 9. 2016, available online at https:// news.zwoelfstaemme.de/2016/01/14/deutschland-wie-behandelst-du-deine-kinder/. 
1. The case of the Twelve Tribes strongly suggests that the creation and adoption of the role of an apostate requires not only specific personal traits, a specific individual situation and/or family circumstances, but most importantly the existence of an opposition against the movement and a wider public demand for such a role. Even though apostates such as Juan Mattatall or Robert Pleyer acted as tools for conflict escalation, a higher level of tension and therefore also the potential for this escalation was already present in the relationship of the movement and general society. In this sense, the role of these men, which may be likened to a catalyst or a detonator, is parallel to the story of Marc Breault, an ex-member of the Branch Davidians, Debora Layton Blake, an ex-member of the Peoples Temple, or Rose-Marie Klaus, an ex-member of the Order of the Solar Temple. At the same time, we need to stress that in all those cases, several factors that escalated the tension were at play.

2. On the other hand, we cannot escape the conclusion that both Pleyer's and Mattatall's adoption of the apostate role was not inevitable and they (and the rest of the influential Twelve Tribes apostates) were pushed to identify with this role by strong emotions provoked by marital and familial conflict and by separation from their close relations. We can compare the strength of these emotions expressed in Mattatall's and Pleyer's open intent to destroy the community or break its facade (which may be the same thing) to Marc Breault's religious fervor, with which he strived to destroy the Davidian community.

However, this does not mean that the personal characteristics of the ex-members were completely unimportant. Even those ex-members who suffer through a court struggle for child custody may avoid adopting the role of an apostate. In 1994, divorced American parents Stuart and Rosemary Lavin underwent a six-month-long court battle for custody in full public spotlight. All their four daughters finally remained with their mother in the Twelve Tribes community, while the father, teacher and writer Stuart R. Lavin, was allowed to visit them. ${ }^{71}$ In 2000, he even joined the movement and spent 4.5 years in the community. After ten more years he wrote a book about the Twelve Tribes. ${ }^{72}$ Even though the text highlights some problematic aspects of the life in the communities, it is, generally speaking, both forgiving and very positive.

3. The cases of the Twelve Tribes raids clearly show that apostates tend to support each other in their actions. At the time of their exit, both Christian Reip and Aaron had a very negative opinion of the movement. Nevertheless, their voice started being heard only after Robert Pleyer rose as an apostate. Up to seven other ex-members adopted the role temporarily after the Focus magazine article was published. ${ }^{73}$ Thirty years before, Juan Mattatall had a similar position among the apostates as Pleyer after him.

${ }^{71}$ Jean A. Swantko, "A 25-year Retrospective on the Impact of the Anti-Cult Movement on our Children" (online), TwelveTribes.prg, retrieved 10. 9. 2016, available online at http://twelvetribes .org/controversies/25-year-retrospective-impact-anti-cult-movement-our-children.

72 Stuart R. Lavin, God's People. In Search of a Destiny. A Look into the Twelve Tribes Messianic Communities, Jerusalem House (Kindle) 2016.

${ }^{73}$ WolfSGRUBER. "Sekten-Aussteiger”, http://www.focus.de/magazin/archiv/tid-26021/glaubens gemeinschaft-zwoelf-staemme-im-focus-report-sekten-aussteiger-sie-brechen-deinen-willen -nochmal-aendern_aid_762194.html. 
4. The cases of the Twelve Tribes raids also show that apostates can gain the trust of the media, activists and authorities. This is probably caused by the fact that they are able to offer insider information to the public. True, all the German opposition against the Twelve Tribes took part in preparing the ground for the raids. Still, it was Pleyer in cooperation with a journalist from an influential network who gave the crucial impulse in September 2013.

The audience interprets the apostate's information as a "disclosure" and a "revelation". This is especially true in those cases where the public distrust of either new religious movements at large or of the one particular movement had already been provoked. Apostates may thus easily create an impression of a double agenda (one private, one public) of those movements, which in turn suggests that the movements' interaction with the public is morally questionable. This is the case of the term "facade" repeatedly used both by Robert Pleyer and Aaron. This inevitably led to the fact that the effectiveness of a tolerant and compromising attitude towards the movement was suddenly called into question. Mutual trust disappeared from the gradually built good relationship between the movement and its neighbours and authorities. In such a situation of a sudden quick change, the members of the Klosterzimmern community felt helpless. ${ }^{74}$ The aforementioned metaphor of the chess figure of a knight seems to be especially fitting in this case. It wouldn't be surprising if the movement's reaction to this kind of moral questioning became secrecy and creation of the double agenda (or, if it really existed, its strengthening).

5. The actions of the Twelve Tribes apostates also remind us that the apostates are hardly unproblematic or objective informers on their communities of origin. Their audience is often fascinated by the atrocity tales and enthralled by the captivity tales that the apostates present as firsthand experiences. On the other hand, a personal experience with the movement in itself guarantees neither a deep understanding of it, nor the ability to see its existence in a wider context. We don't have to accuse the apostates of lying or of evil intentions - we just need to understand that the atrocity tales and captivity narratives can have the biggest significance for themselves.

We can see this in the case of the children that grew up in the closed and to a great extent isolated environment of a Twelve Tribes community. After leaving the movement, they may be confronted with different types of problems. As for Christian Reip, the members of his former community think that for a long time he struggled with his love for computer games, which developed after he left the community, in which he had no access to this kind of activity. ${ }^{75}$ Relationship trouble is also typical after leaving the community and it is probable that the stories that circulate in the movement about crazy romantic experimentation of those who left may have a kernel of truth. Captivity tales and adoption of the role of an apostate may help ex-members to lift the blame, neutralize the consequences of their acts, and serve as a confirmation of the fact that they are mere victims, both of their parents' irresponsible behavior

\footnotetext{
${ }^{74}$ According to a conversation with Twelve Tribes members Caleb and Yerusha (Schüle matrimony) in the Skalná community, 23. 9. 2016.

75 According to a conversation with Obadiah, Caleb and Yerusha in Skalná, 19. 3. 2017.
} 
and of the restrictive rules of the movement, in which they spent their childhood and teenage years.

In Robert Pleyer's case, his apostate role as well as his captivity tale reduces his responsibility for the fact that he joined the movement, became an influential member, and advocated its educational principles and rules and acted in accordance with them for twenty years. Moreover, his collaboration with the opposition allows him to play the part of a "warrior against evil" and thus free himself of the responsibility for his actions during the previous phase in his life. Especially his book Satan Never Sleeps seems to accentuate this function, since the text is one big captivity narrative, showing strikingly little self-reflection. In any case, we need to consider the possibility that Pleyer, as well as other apostates, employed atrocity tales and captivity narratives not only with the conscious intent to tell the truth, warn against danger, achieve retribution, and so on, but also as an expression of unconscious aggression and frustration. Such feelings naturally follow from the disappointment with both the movement and one's own actions, as well as from the fact that all the emotions, time, money, etc. ${ }^{76}$ which the apostate invested in his or her former movement, turned to nothing.

\section{Conclusion}

The circumstances of the police raids both in 1984 in Vermont, which was described in detail by Susan Palmer, and in 2013 in Klosterzimmern and Wörnitz, Germany, which I have outlined in this article, show that if the opposition against a movement allows the apostates to become a major or even the only source of information for authorities or courts, there is a grave danger of unjust power execution that results in inflicting damage, grievances and unjustified violence. The role of apostates as a main source of information is constructed by the media, since the captivity narratives and atrocity tales are of a great commercial value to them. Under the influence of the apostates, the capital of long-standing good relations and trust between the members of the community and both neutral civil servants and local sympathizers may wane quickly. The movement members may be suddenly thrust into a situation of complete social isolation and cast into the role of public enemies. It is therefore not very surprising that the German Twelve Tribes communities dissolved and in 2016 sold the last remnants of their German property.

The journalists are not interested in the problem of apostasy deeply enough to ask about the apostates' motives, including the hidden ones, which even the apostates themselves may not be aware of. This means that for the media and the wide public audiences, the apostates keep playing an unproblematic role of "chess knights". Both scholarly studies and critical reflections of the apostates' actions therefore bear not only an academic, but also a wider social importance.

\footnotetext{
${ }^{76}$ For more information see Rodney Stark and Roger Finke, Acts of Faith, Berkeley, Los Angeles, London: University of California Press 2000, passim.
} 


\section{REFERENCES}

Becker, Claudia, "Sekten-Ausstieg: 'Ich konnte einfach keine Kinder mehr schlagen'” (online), Welt, 9.10.2014, retrieved 10.9.2016, available online at https://www.welt .de/vermischtes/article133084896/Ich-konnte-einfach-keine-Kinder-mehr-schlagen .html.

BeCkford, James, “The Media and New Religious Movements", in James R. Lewis (ed.), From the Ashes. Making Sense of Waco, Lanham: Rowman and Littlefield 1994, p. 143-148.

BeCKFord, James, Cult Controversies: The Societal Response to the New Religious Movements, London, New York: Tavistock 1985, 331 p.

Bromley, David G. (ed.), The Politics of Religious Apostasy: The Role of Apostates in the Transformation of Religious Movements, Westport, London: Praeger 1998, 244 p.

Bromley, David G., "Leaving the Fold. Disaffiliating from New Religious Movements", in JAmes R. LEWIs, The Oxford Handbook of New Religious Movements, Oxford etc.: Oxford University Press 2004, p. 298-314.

Bromley, DAvid G., "The Social Construction of Contested Exit Roles: Defectors, Whistleblowers, and Apostates", in DAVID G. BROMLEy (ed.), The Politics of Religious Apostasy: The Role of Apostates in the Transformation of Religious Movements, Westport, London: Praeger 1998, p. 19-48.

Claudia Frickel, “Die 'Zwölf Stämme’: Brutale Erziehung und strenge Regeln”, Web.de, 23. 5. 2016, retrieved 10.9.2016, available online at https://web.de/magazine/wissen /zwoelf-staemme-brutale-erziehung-strenge-regeln-31575188.

"Deutschland, wie behandelst Du unsere Kinder?" (online), News Zwölf Stämme Herzlich Willkommen, 14. 6. 2016, retrieved 10.9.2016, available online at https://news .zwoelfstaemme.de/2016/01/14/deutschland-wie-behandelst-du-deine-kinder/.

“The Education of our Children”, Island Pond, October 1979, in Foundational Teachings of the Twelve Tribes. Book Two (Di-G), Parchment Press.

Galanter, Marc, Cults. Faith, Healing, and Coercion, New York, Oxford: Oxford University Press 1999, 273 p.

Guyton, Patrick, "Ich hatte keine Kindheit. Ich habe geschufftet" (online), Der Tagesspiegel, 17. 6.2014, retrieved 10. 9. 2016, available online at http://www .tagesspiegel.de/themen/reportage/sekte-zwoelf-staemme-ein-aussteiger-erzaehlt -ich-hatte-keine-kindheit-ich-habe-geschuftet/10044034.html.

Hall, John R., "Public Narratives and the Apocalyptic Sect", in Stuart A. Wright (ed.), Armageddon in Waco: Critical Perspectives on the Branch Davidian Conflict, Chicago, London: The University of Chicago Press 1995, p. 212-228.

HaLl, John R., "The Impact of Apostates on the Trajectory of Religious Movements: The Case of Peoples Temple", in: DAvid G. Bromley (ed.), Falling from Faith: Causes and Consequences of Religious Apostasy, Newbury Park: Sage Publications 1988, p. 229-250.

Herbrich, Vivian, “Die unheimliche Sekte 'Zwölf Stämme': Ein Aussteiger packt aus” (online), Huffington Post, 17. 6. 2014, retrieved 10.9.2016, available online at http:// www.huffingtonpost.de/2014/06/17/sekte-zwoelf-staemme-aussteiger-packt -aus_n_5499399.html.

Introvigne, Massimo, "Defectors, Ordinary Leave-takers, and Apostates: A Quantitative Study of Former Members of New Acropolis in France", Nova Religio $3(1,1999)$ : p. 83-99.

Johnson, Daniel Carson, "Apostates Who Never Were: The Social Construction of Absque Facto Apostate Narratives", in: David G. Bromley (ed.), The Politics of Religious Apostasy: The Role of Apostates in the Transformation of Religious Movements, Westport, London: Praeger 1998, p. 115-138. 
“The Kidnapping of Rebecca Westbrooks" (online), TwelveTribes.org, retrieved 27. 3. 2017, available online at http://twelvetribes.org/controversies/kidnapping-rebecca -westbrooks.

Lavin, Stuart R., God's People. In Search of a Destiny. A Look into the Twelve Tribes Messianic Communities, Jerusalem House (Kindle) 2016, without pagination.

Lewis, James R., "Reconstructing the 'Cult' Experience: Post-Involvement Attitudes as a Function of Mode of Exit and Post-Involvement Socialization”, Sociological Analysis, 47 (2, 1986): p. 151-159.

LüPke-Narberhaus, Frauke, "Leben nach der Sekte: 'Ich habe keine Wurzeln und keine Kraft zu fliegen’” (online), Spiegel Online, 27. 1. 2014, retrieved 10. 9. 2016, available online at http://www.spiegel.de/lebenundlernen/schule/zwoelf-staemme -wie-eine-aussteigerin-versucht-ins-leben-zu-finden-a-944962.html.

Mauss, Armand L., "Apostasy and the Management of Spoiled Identity", in David G. Bromley (ed.), The Politics of Religious Apostasy: The Role of Apostates in the Transformation of Religious Movements, Westport, London: Praeger 1998, p. 51-73.

Our Child Training Manual II., part 12: What Discipline is Not (online), 2000, retrieved 21. 3. 2017, p. 77, available online at https://assets.documentcloud.org /documents/2994399/OUR-CHILD-TRAINING-MANUAL.pdf.

Palmer, Susan J., "Frontiers and Families: The Children of Island Pond", in Susan J. Palmer and Charlotte E. Hardman (eds.), Children in New Religions, New Brunswick: Rutgers University Press 1999, p. 157-161.

Palmer, Susan J., "Sekten in Germany: The Case of the Twelve Tribes", a paper presented at the IAHR Conference, Erfurt, 27. 8. 2015.

Palmer, Susan, "Apostates and their Role in the Construction of Grievance Claims Against the Northeast Kingdom/Messianic Communities", in DAvid, G. Bromley, (ed.): The Politics of Religious Apostasy: The Role of Apostates in the Transformation of Religious Movements, Westport, London: Praeger 1998, p. 191-208.

Pleyer, Robert, and Axel Wolfsgruber, Der Satan schläft nie: Mein Leben bei den Zwölf Stämmen, München: Knaur 2014, 266 p.

The Purpose of Creation \& Redemption (online), a Twelve Tribes freepaper, TwelveTribes. com, retrieved 21. 3. 2017, available online at http://www.twelvetribes.com/articles / purpose-creation-redemption.

"Razzia bei Sekte '12 Stämme' - RTL-Reporter liefert Beweise für Kindesmisshandlung” (online), RTLNext.RTL.de, 5. 8. 2014, accessed 10.9.2016, available online at http:// rtlnext.rtl.de/cms/razzia-bei-sekte-12-staemme-rtl-reporter-liefert-beweise-fuer -kindesmisshandlung-1620767.html.

Shupe, Anson D., and David G. Bromley, "Apostates and Atrocity Stories: Some Parameters in the Dynamic of Deprogramming", in Bryan Wilson (ed.), The Social Impact of New Religious Movements, Barrytown: Rose of Sharon Press 1981, p. 179-234.

Solomon, Trudy, "Integrating the 'Moonie' Experience: A Survey of Ex-Members of the Unification Church", in Thomas Robbins and Dick Anthony (eds.), In Gods We Trust: New Patterns of Religious Pluralism in America, Princeton: Rutgers University Press 1981, p. 275-294.

Stark, Rodney, and Roger Finke, Acts of Faith, Berkeley, Los Angeles, London: University of California Press 2000, 349 p.

Swantko, Jean A., "A 25-year Retrospective on the Impact of the Anti-Cult Movement on our Children" (online), TwelveTribes.prg, retrieved 10.9.2016, available online at http://twelvetribes.org/controversies/25-year-retrospective-impact-anti-cult -movement-our-children. 
Swantko Wiseman, Jean, "Spanking Bans and the Faith of Families: The Twelve Tribes in the European Court of Human Rights", a paper presented at CESNUR conference, Jerusalem, 3. 7. 2017.

Tabor, James D., and Eugene V. Gallagher, Why Waco?, Berkeley etc.: University of California Press 1995, 256 p.

Wolfsburger, Axel, "Der Krieg um Gottes Kinder” (online), FOCUS Magazin 47 (2002), 18.11. 2002, retrieved 14.3. 2017, available online at http://www.focus.de /panorama/reportage/reportage-der-krieg-um-gottes-kinder_aid_206210.html.

Wolfsgruber, Axel, “Sekten-Aussteiger: 'Sie brechen Deinen Willen'” (online), FOCUS Magazin 21 (2012), 21. 5. 2012, retrieved 10. 9. 2016, available online at http://www .focus.de/magazin/archiv/tid-26021/glaubensgemeinschaft-zwoelf-staemme-im-focus -report-sekten-aussteiger-sie-brechen-deinen-willen-nochmal-aendern_aid_762194 .html.

Wright, Stuart A., "Exploring Factors That Shape the Apostate Role", in David G. Bromley (ed.), The Politics of Religious Apostasy: The Role of Apostates in the Transformation of Religious Movements, Westport, London: Praeger 1998, p. 95-114.

Wright, Stuart A., Leaving Cults: The Dynamics of Defection, Washington: Society for the Scientific Study of Religion 1987, 124 p.

Wright, Stuart A., and Susan J. Palmer, Storming Zion: Government Raids on Religious Communities, New York: Oxford University Press 2016, 288 p. 